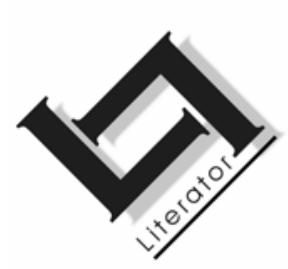

\title{
Die gebruik van humor om kreatiewe skryf in die onderrig van Afrikaans te stimuleer: 'n gevallestudie
}

\author{
Estelle Kruger \\ Kurrikulumstudie \\ Fakulteit Opvoedkunde \\ Universiteit van Stellenbosch \\ STELLENBOSCH \\ E-pos: ekruger@sun.ac.za
}

Thomas Edison: 'I never did a day's work in my life - it was all fun.' (Torok et al., 2004.)

\section{Abstract}

The use of humour to stimulate creative writing in the teaching of Afrikaans: a case study

This article reports on of a qualitative research programme in which humouristic material was used as part of an Afrikaans language teaching programme. The primary participants in this programme were education students at Stellenbosch University who intend to teach Afrikaans in secondary schools. The ways in which humour can influence the classroom atmosphere and form part of cultural experience are also discussed. Specific attention is given to the use of humouristic material to facilitate creative writing as part of the relevant teaching programme. The humour of adolescents is discussed, especially the use of sarcasm and non-sense humour which can possibly contribute to discipline problems in the classroom.

Finally, the researcher reports on the analysis of one of the students' parodies as a case study. Analysis and interpretation of the parodic text revealed several forms of creativity - parody as burlesque, dialogue between codes, postmodern metafiction, manifestation of divergent thinking, and play with words and boundaries. 


\section{Opsomming}

Die gebruik van humor om kreatiewe skryf in die onderrig van Afrikaans te stimuleer: 'n gevallestudie

Hierdie artikel is 'n verslag van 'n kwalitatiewe ondersoek na die gebruik van humormateriaal in die onderrig van Afrikaans aan 'n groep onderwysstudente aan die Universiteit van Stellenbosch wat beoog om Afrikaans in sekondêre skole te onderrig. Die navorser toon aan hoe humor die klaskameratmosfeer kan beïnvloed en dat die gebruik van humormateriaal die proses van kreatiewe skryf kan fasiliteer. Die humor van adolessente word bespreek, veral die gebruik van sarkasme en onsinhumor wat dalk in die klaskamer dissiplineprobleme kan veroorsaak.

Uiteindelik word verslag gedoen van die navorser se ontleding van een van die onderwysstudente se parodieë as 'n gevallestudie. Verskillende vorme van kreatiwiteit wat in die parodieteks gemanifesteer het, word aangedui. Aandag word gegee aan die spesifieke parodie as burleske, die dialoog tussen kodes, postmoderne metafiksie, die manifestasies van divergente denke en die outeur se spel met woorde en grense.

\section{Inleiding}

Ervaring in die onderrig van Afrikaans in verskeie onderwyskontekste (huis- en addisionele taal, sekondêr en tersiêr) het die navorser laat besef dat kreatiewe skryftake moeilik is om te medieer en te assesseer, en dat die meeste leerders nie werklik daarin geïnteresseerd is om "opstelle" te skryf nie, dalk omdat hulle tog maar net weer dieselfde punt sal ontvang as die vorige keer en nie noodwendig kan agterkom wat reg of verkeerd is in dit wat hulle geskryf het nie. Kreatiewe skryf is 'n deel van die Afrikaansonderrigkurrikulum wat op skool nie baie aandag kry nie. Een rede hiervoor is moontlik dat daar soveel ander gedeeltes van die kurrikulum is wat geëksamineer moet word. Verder het die meeste onderwysers nie self opleiding in kreatiewe skryf ontvang nie. Leerders met kreatiewe skryftalent vorder dus óf op hulle eie, óf glad nie.

Leerders se onbevredigende (negatiewe) en onbelangstellende houding teenoor die onderrig van Afrikaans (Bosch, 1995:18) is moontlik vererger deurdat hulle negatiewe stereotipes opgebou het dat taalonderrig vervelig en vol reëls is en nie noodwendig met hulle lewenswerklikheid verband hou nie. Leerders se negatiewe stereotipes kan gerelativeer word indien hulle bewus gemaak kan word van Afrikaans as taal en van 'n ander aspek van die Afrikaans- 
sprekende kultuur, naamlik die humoristiese, soos dit in humoristiese Afrikaanse tekste voorkom.

Die gebruik van humor as onderriginstrument in die taalonderrigkonteks kan bydra tot die ontwikkeling van leerders se talente (Landvogt, 2001) en kommunikatiewe vaardighede. Volgens Nilsen en Nilsen (1999) lei dit ook tot die uitbreiding van opvoeders se kennis van leerders se affektiewe behoeftes en daardeur kan opvoeders se onderrig- en assesseringsvaardighede bevorder word.

Daar is heelwat skerp, hoogs intelligente leerders in skole (dikwels seuns) wat met gesofistikeerde, absurde ironie (non-sense humor; Ruch, 1999) uiting gee aan hulle verveeldheid met en hulle passiewe rebellie teenoor die rigiditeit van die sisteem en (volgens hulle: irrelevante) kurrikula waaraan hulle onderworpe is - ' $n$ verskynsel wat Herangi (2002:3) die samelewing se "sausage machine" noem. Laasgenoemde leerders veroorsaak dikwels dissiplineprobleme (Dreyer, 2005:24) indien onderwysers nie bewus is van die groter subkulturele konteks waarvan hierdie leerders deel is nie; en ook nie besef dat die postmoderne generasie alle nosies en sogenaamde erkende uitdrukkings van kennis, die werklikheid, waarheid en outoriteit bevraagteken en wantrou nie. Humormateriaal kan onderwysers help om hierdie meer intelligente leerders se humor te verstaan en te aanvaar as kritiese uitdrukkings van hulle identiteit.

Die belangrikste doelwit van hierdie artikel is om te beskryf hoekom humormateriaal as basis gebruik kan word vir die ontwikkeling van onderrigstrategieë om kreatiewe skryf in Afrikaans te bevorder. Uiteindelik sal een van die parodieë wat 'n onderwysstudent (Müller, 2006) as deel van 'n onderrigprogram deur die gebruik van humormateriaal geskep het (Kruger, 2006a), as gevallestudie bespreek word. Daarmee saam sal die portuurlesers se resepsie van hierdie parodie en die outeur se beplanning en refleksie oor die onderrig- en skryfprogram ook geïntegreer word. Hierdie artikel is dus 'n opvolgstudie van 'n vorige artikel (Kruger, 2006b) waarin die hele groep onderwysstudente se parodieë as hibridiese tekste bespreek is.

\section{Humor en taalonderrig}

Motivering vir die bestudering en skryf van die parodie as stylfiguur kan gevind word in die feit dat Bartho Smit se Die keiser (1977), 'n satiriese parodie op Hans Andersen se sprokie "Die keiser se nuwe klere", voorgeskryf is vir graad 12-leerders in die Wes-Kaap (WesKaapse Onderwysdepartement, 2005). Die onderwysstudente wat 
deel van die navorsingsprogram was, het hulle voorberei om Afrikaans as vak te onderrig vir leerders in die sekondêre skool - dit impliseer dat hulle Smit se parodie behoort te ken, te verstaan en in die onderrigsituasie moet kan gebruik. Die taak waarvoor die onderwysstudente in die onderrigprogram voorberei is (Kruger, 2006a), was juis om parodieë aan die hand van bekende sprokies (ook tradisionele volksverhale) te skryf.

\subsection{Humor en die klaskamer}

Humor kan die kwaliteit van lewe en die proses van taalonderrig verbeter. Medgyes (2002:3), asook Pollak en Freda (1997) stem saam dat die gebruik van humor in onderrig tot effektiewe leer kan bydra. Die funksies van humor in die onderrig-en-leersituasie kan opgesom word as die opbou van verhoudings, die bemagtiging van leerders, die stimulering van kreatiewe denke en belangstelling, die opbou van 'n selfbeeld en sosialisering om houdings, motivering, leerder-outonomie en selfwerksaamheid te bevorder (Aoki, 1999).

Kher, Molstad en Donahue (1999) meen dat humor 'n waardevolle onderriginstrument is om 'n klaskameratmosfeer te skep wat leer interessanter maak en dus bevorder. Hulle beklemtoon dat geskikte en gepaste humor onderlinge openheid en respek kan bewerkstellig en verwys na die navorsingsgetuienis in verband met die verhouding tussen onderwyser en leerder en hoedat entoesiasme en humor aansteeklik kan wees.

Onderwysers speel 'n kritieke rol in die skep van kreatiewe leeromgewings. Die gebruik van humor en humormateriaal kan as katalisator bydra om kommunikasie te bevorder en konflik te ontlont (Kher et al., 1999). Behalwe dat humor in die vorm van grappe, raaisels, dubbelsinnighede, snaakse verhale, humoristiese kommentare, strokies, lawwe verse (soos limerieke) en kamma-eksperimente in lesings, toetse of eksameninstruksies gebruik kan word, kan dit leerders se waardering vir die inhoud verhoog. Uit ondersoeke is dit duidelik dat leerders 'n voorkeur vir strokieshumor toon en dat strokies in handboeke tot 'n ontspanne leeratmosfeer lei (Lyttle, 2001).

Verskeie navorsers toon aan dat humormateriaal gebruik kan word om aandag, begrip, geheue en motivering te fasiliteer (Cook, 2000; Minchew, 2001; Belz, 2002). Die onderwyser se sin vir humor kan ook daartoe bydra dat leerders ontspan en minder angs ervaar, spesifiek in die geval van sogenaamde ingewikkelde vakke soos wis- 
kunde, natuurwetenskap en statistiek (Bryant, Comisky \& Zillmann, 1979; Kher et al., 1999; Peters, 2003).

Dewitte en Verguts (2001:40) meen dat 'n sin vir humor daaruit bestaan dat iemand grappe kan genereer en sensitief vir die sosiale omgewing is. Verskeie navorsers maak aanbevelings hoe onderwysers hulle sin vir humor kan ontwikkel (Berk, 1998; Chiasson, 2002; Ulloth, 2003:35-36).

Lyttle (2001) meen dat onderwysers kennis behoort te neem dat ironiese humor effektiewer as spotprente is en dat selfspottende (self-effacing) humor die beste effek het. Ook Berk (1998:47), 'n professor in statistiek aan die Johns Hopkins Universiteit, maak suksesvol gebruik van selfspot - hy meen dat dit leerders aanmoedig om hom as toeganklik te ervaar. Dit help ook skaam leerders om deel te neem, omdat dit hulle vrees om foute te maak, verminder (Pollak \& Freda, 1997; Chiasson, 2002).

Alderman en Popke (2002) beskryf hoe hulle in ooreenstemming met die navorsing van Coleman (1992) humoristiese films en televisieprogramme as onderrigmateriaal insluit. Daarmee stel hulle leerders aan verskillende waardes en perspektiewe bloot en stimuleer hulle om hul eie en ander se vanselfsprekende veronderstellings en lewens- en wêreldbeskouings krities te ondersoek. Hierdie studie van Alderman en Popke lewer getuienis dat humormateriaal leerders se kritiese denke kan ontwikkel - die inkongruensie en jukstaponering van verskeie teenoorstaande konseptualiserings in die verhale dra daartoe by dat konvensionele sienings van realiteit uitgedaag en ondermyn word. Leerders se kognitiewe buigbaarheid ontwikkel omdat hulle heen en weer tussen verskeie standpunte moet beweeg. Alledaagse aanvaarde patrone wat in die samelewing manifesteer, kan dus deur die humorervaring arbitrêr en subjektief word. Weber (2000) gebruik taalspel (herhaling, oordrywing en onverwagte assosiasies, metafore en vergelykings) en humormateriaal uit outentieke mediatekste om sy leerders te stimuleer om krities oor hulle wêreld te laat dink. Verder gebruik hy speelse skryfstyle (wat humor tot gevolg het) soos die parodie, rap en limerieke om sy leerders bekende en bestaande materiaal (polisieverslae, sprokies, klassieke verhale, sportverslae, skinderkolomme en koerantartikels) te laat herskryf.

Alderman en Popke se studie (2002) bevestig die gevaar dat humoristiese stereotipes die klaskameratmosfeer negatief kan beïnvloed en leerders kan vervreem of ongelykheid kan veroorsaak. Tog meen hulle dat humor klaskamerkommunikasie kan bevorder en 
belangstelling kan verhoog, sowel as die selfbeeld van studente kan verbeter en dat humor ' $n$ openbare forum kan bied waarbinne politieke, sosiale en morele kwessies bespreek kan word.

Humormateriaal moet dus sensitief gekies en gebruik word, veral omdat dit aanstootlik kan wees vir individue en groepe - spesifiek stereotipes oor godsdiens, ras, politiek en geslag (Berk, 1998:44; Kher et al., 1999; White, 2001; Torok, McMorris \& Lin, 2004). Veral ook die gebruik van sarkasme en skimpe as humor om leerders belaglik te laat lyk, te intimideer of subtiel te straf, kan kontraproduktief wees (Chiasson, 2002; White, 2001:346; Kirsh \& Kuiper, 2003:34). Tog vind Torok et al. (2004:17) in hulle studie dat voorgraadse studente sarkasme as een van hulle top-drie keuses vir gepaste humor aangedui het.

Omdat humor tot die klasatmosfeer kan bydra, is dit moontlik dat humor ook as onderwerp bestudeer kan word. In hierdie verband stel Endlich (1993:181-182) die volgende items vir invoeging in die sillabus vir psigologiestudente (lees: onderwysstudente) voor: humorteorieë (superioriteit, ontlading en inkongruensie), hoe om kinders se sin vir humor te ontwikkel, gesondheidsaspekte van humor, humor as terapie, humor en persoonlikheid, die verband tussen humor en kreatiwiteit en kulturele aspekte van humor.

Die feit dat humormateriaal gebruik kan word om onderwysstudente (en leerders) die wêreld waarin hulle leef krities te laat beskou, impliseer dat 'n mens in die taalonderrigsituasie behoort rekening te hou met die ontwikkeling van deelnemers aan die taalonderrigsituasie, spesifiek die humor van adolessente.

\subsection{Humor en adolessensie}

Dit is moontlik dat veral seuns op hoërskool absurde humor as 'n vorm van (passief-aggressiewe) magspel gebruik om onderwysers te frustreer. Ruch (1999) beskryf in sy studie oor verskillende persepsies van humor die verskynsel van absurde humor, wat hy onsinhumor (non-sense humor) noem. Onderwysers en inwonende personeellede in sekondêre skoolkoshuise kan getuig dat hierdie soort humor kenmerkend is van hoogs intelligente adolessente seuns. Advertensies op televisie wat op adolessente jongmans gerig is, wys dat die bemarkers se kommunikasiestrategieë duidelik gerig is op die droë humorsin van hierdie teikengroep (byvoorbeeld Savannah Dry en Kentucky Fried Chicken in 2006). 
Zuckerman (1994:199 e.v.) toon met getuienis uit 'n verskeidenheid navorsingstudies (oor gedragsuitdrukkings en gepaardgaande biososiale faktore) aan dat daar 'n beduidende verband tussen humor en die soeke na opwinding bestaan. Hierdie soeke bereik 'n hoogtepunt in adolessensie (Zuckerman, 1994:108). Volgens Ruch (1988, aangehaal in Zuckerman, 1994:219, 220) is die humor waarvan opwindingsoekers hou veral grappe en spotprente wat gepaard gaan met onoplosbare inkongruensie-, seksuele-, non-sense- en ondermynende humor. Zuckerman meen dat die voorkeur van hoë opwindingsoekers waarskynlik verband hou met hulle verdraagsaamheid van dubbelsinnigheid (ambiguity), komplekse ontwerpe en kunsvorme. Verwante persoonlikheidseienskappe is impulsiwiteit, avontuurlikheid, ry-die-golf-houding (surgency), super-egosterkte, radikalisme, 'n liberale lewensuitkyk en psigotisisme. Dit blyk uit navorsing dat die soeke na opwinding sterk verband hou met hormoonafskeiding, bloedsamestelling, chemiese breinfunksionering, aggressie en 'n behoefte aan outonomie (Zuckerman, 1994:69-72, 100101).

Omdat twee uiterstes van humorervaring moontlik is, dit wil sê 'n genoeglike (en meer positiewe "lag saam met"-) humor en 'n skeptiese (meer negatiewe "lag vir"-) humor, meen Ruch (1999) dat albei soorte humor affektief-motiverende en kognitiewe elemente bevat en dat die aanvanklike ongeloof opgehef word deur die genoegdoening wat met die ontvanger se probleemoplossing gepaard gaan. Die probleem met absurde humor is dat daar onmoontlike (en onoplosbare) inkongruensie in die boodskap is en dat die ontvanger se tydelike opskorting van ongeloof ("suspense of disbelief") gefrustreer en (negatief) gemanipuleer word, deurdat nuwe absurditeite en inkongruensie veroorsaak word.

Aansluitend by skrywers se bevindings dat nuwe strategieë gevind moet word om adolessente te onderrig, wil die navorser argumenteer dat die gebruik van humormateriaal 'n alternatiewe onderrigstrategie in die taalklaskamer kan bied. Motivering daarvoor kan in veral Kenway en Bullen (2003:160 e.v.) se bespreking gevind word - 'n bespreking waarin hulle aantoon hoe om gewilde kultuur in leerinhoude te integreer. Ook Bakhtin se konsep van die karnavaleske, humor, parodie en postmodernisme bied kreatiewe moontlikhede in huistaalonderrig (Nehring, 2003:73-75).

Dit is reeds aangedui dat humor verband hou met die sosio-kulturele konteks waarbinne deelnemers aan die taalonderrigsituasie leef. Hierdie deelnemers word deur Kruger (2006a) beskryf as Generasie $\mathrm{X} / \mathrm{Y} / \mathrm{Z}$. ' $\mathrm{n}$ Deel van hierdie konteks is ook die feit dat onderwys- 
studente en hoërskoolleerders met wie hulle werk, kultuurskeppers kan wees. Humormateriaal kan dus gebruik word om hulle kreatiwiteit te ontwikkel.

\subsection{Humor as kreatiewe uiting}

Aangesien aspekte van kreatiwiteit 'n groot rol gespeel het in die onderrigprogram as deel van die navorsingsprogram ter sprake (Kruger, 2006a), en die onderrig plaasgevind het met die oog op kreatiewe skryf in Afrikaans as huistaal, was dit belangrik om vas te stel in watter mate hierdie student (Müller, 2006) se parodie tekens van kreatiwiteit toon. In die volgende bespreking word eers gelet op die ooreenkomste wat daar tussen humor en kreatiwiteit (spel, fantasie en verbeelding) is, om sodoende die verband te lê tussen die gebruik van humormateriaal en die skryf van parodieë deur die onderwysstudente in die genoemde navorsingsprogram.

Reeds in die tweede helfte van die vorige eeu toon verskeie navorsers - aangehaal deur Babad (1973) - aan dat daar 'n beduidende verband bestaan tussen humor en kreatiwiteit. Die positiewe korrelasie tussen humor, spel en kreatiwiteit is verder volgens Wycoff en Pryor (2003) deur verskeie studies bevestig.

Domino et al. (2002:20) se navorsing met tersiêre studente toon aan dat daar 'n beduidende korrelasie tussen humor en kreatiwiteit is. Verder toon Babad $(1973: 621,625)$ en Shade (1999:47) aan dat dit veral met betrekking tot die vlotheid van idees, divergente denke en aanpasbaarheid is wat humor met kreatiwiteit verband hou en dat 'n humoristiese persoon dus per definisie kreatief is, hoewel nie elke kreatiewe oplossing humoristies is nie.

'n Studie met graad agt-leerders steun die hipotese dat die begryp van verbale humor geassosieer kan word met formele operasionele denke (Couturier, Mansfield \& Gallagher, 1981:224). Verder toon Crawford en Gressley (1991:224) aan dat humor verband hou met kreatiewe taalgebruik, hoewel daar in hulle ondersoek verskille tussen die humoruitdrukkings van manlike en vroulike proefpersone gevind is.

Daar is 'n ooreenkoms tussen Freud (1916) en Koestler (1969) se opvattings dat gevatheid die kognitiewe, kreatiewe transformasie van woorde en idees behels (Feingold \& Mazzella, 1993). In laasgenoemde navorsers se studie word aangetoon dat humoruitings 'n kreatiewe proses van humormotivering, humorbegrip en humorkommunikasie behels. Hulle lewer ook getuienis daarvan dat verbale 
vermoë en kreatiwiteit 'n positiewe korrelasie toon met ouderdomsgroei vanaf adolessensie tot die middeljare.

Teoretici se omskrywings van humor vestig die aandag op verskeie elemente van kreatiwiteit, naamlik teenstrydigheid en onverwagsheid (verrassing). Die humorrespons word ook gestimuleer deur die onsekerheid of onaanpasbaarheid (inkongruensie) wat voortkom uit die bymekaarbring van elemente waaruit 'n grap of dubbelsinnige taalgebruik bestaan - alles aspekte van kreatiwiteit (Fry \& Allen, 1996:247).

Vosloo (2003:44) bespreek die ooreenkoms tussen kreatiwiteit en humor en maak die stelling dat, benewens die funksie om te vermaak, humor ook meewerk in belang van groter konseptualisering, insig, begrip, meelewing, empatie en 'n besef van kontekstualiteit by die ontvanger. Ook De Bono (1990:45) meen dat humor 'n meer betekenisvolle proses in die menslike verstand is as die rasionele, omdat humor die individu se buigsaamheid bevorder. Kuhrik, Kuhrik en Berry (1997) bespreek die waarde van humor om kreatiwiteit te bevorder, veral omdat inkongruensie leerders se divergente denke ontwikkel.

\subsection{Humor en spel}

Soos kreatiwiteit, hou humor verband met spel. Humor is net so vlugtig en moeilik om te definieer, en net so kultureel gekondisioneer soos spel. Albei word egter as genotvolle aktiwiteite ervaar, en albei kan 'n glimlag of luide lag as reaksie uitlok. Die skeidslyn tussen humor en spel is dus baie fyn, omdat albei kruiskulturele en intrakulturele kontekstuele variasies in gedrags- en kognitiewe aspekte toon.

Verskeie sienings word by teoretici gevind oor die verhouding tussen spel en humor. Apte (1985:89) haal Huizinga (1944) aan wat meen albei is die teenoorgestelde van erns; albei weerstaan alle pogings om dit te reduseer tot ander terme; albei se logiese begronding en onderlinge verhouding moet in 'n baie diep laag van 'n mens se gees ingebed lê. Apte verwys ook na Norbeck (1976) wat argumenteer dat spel dikwels met geestigheid en humor verband hou, maar tog nie sinoniem daarmee is nie.

Humor kan gesien word as enige spel wat saamgaan met 'n glimlag of 'n lag tot gevolg het. Humor is grootliks deel van ongestruktureerde spel en spel wat nie kompetisie inhou nie, en sowel humor as spel word gewillig onderneem (Apte, 1985:91). Die konteks van 
spel is essensieel vir alle humor (Fry \& Allen, 1996:249). Speelse aktiwiteite word uitgevoer ter wille van sigself of ter wille van genot. Dit staan in teenstelling met ernstige aktiwiteite wat te doen het met maklik identifiseerbare liggaamlike behoeftes, eksterne bedreigings of spesifieke praktiese doeleindes.

In sowel humor as spel is daar fases van spanning, opwinding, verligting van spanning en ontspanning (Berlyne, 1969, aangehaal in Fry \& Allen, 1996:249). Dit is bekend dat spel die humorvaardighede van kinders kan voed en versterk en spel behels presimboliese aktiwiteite, emosie, intuïsie en pret (Root-Bernstein, 1999, aangehaal in Weiss, 2001). Fry en Allen (1996:248) merk op dat sowel humor as spel sosiale waarde en vele praktiese gebruiksmoontlikhede het.

Eco (1986:275) se opmerking dat humor 'n spel met grense en reëls is, sluit aan by wat Weiss (2001) en Robertson (1980:52-58) argumenteer, naamlik dat kreatiwiteit kennis en dissipline behels: kennis van die terrein waarop gewerk word, 'n ingesteldheid om na nuwe probleme te soek en om dit verby die grens van die bekende te waag. Kreatiewe denke impliseer die uitbreiding van die beperkings van bestaande kennis (Honig, 2001), sowel as die oorsteek van die grens tussen spel en werklikheid (Robertson, 1980:35). Hierby sluit Broner en Tarone $(2001: 495,496)$ se siening aan, naamlik dat taalspel deel van humor is. Hulle verwys na Cook (2000) se studie van spel en taal, die skryf van parodieë as nabootsing van 'n bestaande vorm, en Bakhtin se konsep van die karnivaleske.

Prather (1995, aangehaal in Weiss, 2001) stel prettige snellers (happy triggers) voor as kreatiewe aktiwiteit; dit behels om assosiasies tussen twee ongelyksoortige dinge te makk in ooreenstemming met Koestler (1969) se konsep van bi-sosiasie, die omkering van veronderstelde aannames, om buitengewone, gekke of oënskynlik onmoontlike voorstelle (outrageous suggestions) tydelik toe te laat en nuwe verbande te lê (Honig, 2001).

Soos wat humor 'n spel met taboes is (Freud, 1916; Eco, 1986:275; Van Niekerk, 2001), is kreatiwiteit 'n blootstelling aan dubbelsinnige jukstaposisionering van inkongruensie (Rothernberg, 1986, aangehaal in Simonton, 1999). Ook Bruner (1962, aangehaal in Robertson, 1980:24) noem paradokse as voorwaardes vir kreatiwiteit. Bruner meen dat kreatiewe denke ' $n$ spel is tussen losmaking en betrokkenheid, tussen drif en welvoeglikheid. Humor sowel as spel behels die vryheid om deur die objek gedomineer te word, uitstel en onmiddellikheid en vrae sonder antwoorde. Spel ontwikkel die ver- 
moë om die aandag in 'n mate te versprei; om terug te val op primêre kognisie; om die onbewuste en intuïtiewe kragte toe te laat om op die probleem in te werk en om sluiting uit te stel - om te kan wag op die onbekende verrassing. Hierdie soort spel met die ongewone behels metakognitiewe ervarings en die omkering van bestaande kennis en norme (Pesut, 1990, aangehaal in Abdallah, 1996).

\subsection{Humor en fantasie}

Nog 'n sleutelfaktor wat met humor gepaard gaan is fantasie of verbeelding, wat self deel is van kreatiwiteit. Volgens verskeie navorsers word verbeelding en fantasie as 'n belangrike element by kreatiwiteit of kreatiewe probleemoplossing beskou (Cattell, 1987; Basadur et al., 1990; Khatena, 1987, aangehaal in Malan, 1996:82). In McGhee (1979) se langtermynondersoek oor die ontwikkeling van humor bevind hy dat humorontwikkeling verband hou met fantasiespel waarin kinders leer om vir inkongruensie te lag.

Humor verskaf die moontlikheid om die werklikheid deur verbeelding met meer kreatiwiteit en minder kwesbaarheid te benader. Humor stimuleer kreatiwiteit en maak die leser se horisonne wyer deur te ontsnap aan lineêre, logiese, praktiese denke. Verhale is produkte van 'n skrywer se vrugbare verbeelding, en maak dikwels die onmoontlike 'n werklikheid. Verbeelding wek innerlike moontlikhede op - die bevrediging van (soms onmoontlike) begeertes en die voorlopige deurwerking en beheersing van basiese vrese deur middel van fantasie, verbeeldingsvlugte as gedagte-avonture en magiese transformasies (soos wat in parodietekste die geval is).

Vervolgens word 'n diepgaande bespreking van een van die onderwysstudente se parodieë as 'n gevallestudie gegee (Müller, 2006).

\section{Bespreking van 'n parodie as uitkoms van 'n navor- singsprogram}

\subsection{Agtergrond tot die student se parodie as 'n navorsings- uitkoms}

Die navorsing is gedoen met aspirant-opvoeders wat hulle voorberei het om Afrikaans in hoërskole te onderrig. In 'n vorige artikel (Kruger, 2006b) word hierdie navorsingsprogram beskryf waartydens dertien nagraadse onderwystudente die taak gehad het om parodietekste uit bekende sprokies te skep. Die parodietekste is ten nouste verweef met hulle eietydse massa- en studentekultuur. 
Twaalf van hierdie studente was dames (twee bruin en tien wit) en saam met hulle in die groep was een wit man. Almal was Afrikaanssprekend en het reeds ten minste drie jaar voorgraadse studie agter die rug gehad. Twee van die wit damestudente was reeds oorsee vir langer tydperke as bloot 'n vakansie en baie van hulle is van plase of die platteland afkomstig. Buiten een bruin dame (woonagtig in die Paarl en 33 jaar oud) was al die studente ongetroud, woonagtig in koshuise, studentehuise of woonstelle te Stellenbosch en hulle het in die ouderdomsgroep tussen 21 en 26 geval.

Die studente is eers as deel van 'n onderrigprogram aan 'n verskeidenheid humormateriaal blootgestel (Kruger, 2006a). Deur middel van die onderrigprogram het die navorser gepoog om 'n bydrae te lewer en leemtes te vul in die onderrig van Afrikaans aan onderwysstudente deur stimulering en onderrig van hulle kreatiewe denke aan die hand van enkele beginsels van kreatiwiteit en die proses van kreatiewe skryf. Daar is gekonsentreer op die mediëring van tradisionele literatuur en fasilitering met die oog op die skryf van kreatiewe tekste. Terselfdertyd wou die navorser die studente se kritiese geletterdheid bevorder. Uiteindelik was die bedoeling om die studente met behulp van die onderrigprogram toe te rus om humormateriaal tydens hulle volgende skoolbesoekgeleentheid te gebruik.

Die navorser het gehoop dat die onderwysstudente met die skryf en lees van die humoristiese tekste sou begin dink aan parodie as 'n simboliese aktiwiteit eerder as net onskuldige humor. Die doel hiervan was om studente aan te moedig om hulle fokus te verskuif van lees en skryf na interpreteer, asook van 'n relatief onbewuste aktiwiteit van enkodering en dekodering na 'n meer kritiese omgaan met die kulturele stelsels waarvan hulle deel uitmaak (Curnutt, 1996). 'n Belangrike deel van die onderrigprogram was dus bestaande sprokie-parodieë (Dahl \& Blake, 1982; Garner, 1994; De Vos \& Grobler, 1999) en die elemente van die parodie wat as 'n stylfiguur (Band, 1990; Pretorius, 1992) aan hulle voorgehou is. Die opdrag was dat hulle 'n tradisionele sprokie kon kies en die karakters, ruimte en tyd verander soos wat hulle wou. Hulle moes hierdie dele aanmekaarsit en 'n parodie met 'n intrige skep wat pas in die konteks van hulle huidige samelewing. Hulle kon in hulle parodieë met die samelewing spot soos hulle wou.

Die doel met die onderrigprogram was dat hierdie studente toegerus moet word om te reflekteer en krities te reageer op letterkunde, kuns en kultuur, sowel as op sosiale, politieke en ekonomiese sake. Op hierdie manier kon die program daartoe bydra dat die studente as kritiese denkers in hulle eie samelewing ontwikkel, in aansluiting by 
Hutcheon (1985:85) wat parodie beskou as een van die tegnieke van selfreferensialiteit waardeur 'n bewussyn van die konteksafhanklikheid van betekenis op estetiese wyse geopenbaar word. Hutcheon meen dat die omstandighede wat enige uiting omring 'n belangrike deel van die betekenisgewing uitmaak.

Aan die einde van die onderrigprogram het die navorser 'n refleksieonderhoud met die studente (as outeurs van die parodieë) gehad. Hierdie onderhoude is opgeneem, getranskribeer en as data opgeteken. Die doel van hierdie onderhoud was om die studente kans te gee om intensief te reflekteer oor al die aspekte van die onderrigprogram oor die gebruik van humormateriaal in die onderrig van Afrikaans, waaraan hulle blootgestel is.

Die teikengroep se parodieë as kreatiewe taaluitings met humormateriaal as stimulus, is waargeneem en beskryf en uiteindelik is patrone, temas en verduidelikings geanaliseer (Babbie \& Mouton, 2001:283) om veralgemenings te vind. Om die resepsie van die parodietekste te bepaal, het die navorser onderhoude gevoer met bruin en wit, dame- en manstudente (almal Afrikaanssprekend) as portuurlesers, om te bepaal watter breë kulturele (en meer spesifiek, kampuskulturele) projeksies hulle in die verhale gevind het. Die opdrag was oop en hulle is gevra om verslag te doen van die kulturele temas wat hulle herken het. Die portuurlesers het elkeen hulle eie opsomming of ontleding daarvan in die stories gemaak. Hutcheon (1985) beklemtoon die waarde van die leser se resepsie as dekodering van die outeur se enkodering. Dit is dus nie net die produksie van parodietekste wat belangrik in die navorsingsgebeure is nie, maar ook die resepsie daarvan. Al is die outeur (van die Romantiek) as die skepper en oorsprong van betekenis wel "dood", soos wat Barthes reeds in 1972 (Hutcheon, 1985:85) geargumenteer het, is die outeur se posisie van diskursiewe outoriteit steeds geldig, en selfreferensialiteit word toenemend 'n fokusarea binne die postmodernisme. Die tweede groep portuurlesers (almal wit dames) het elkeen drie verskillende parodietekste (deur die onderwysstudente geskryf) gekry om te lees met 'n vraelys daaroor wat hulle moes beantwoord.

Om vas te stel watter soort parodie elkeen van die studente in die navorsingsprogram (Kruger, 2006a) geskryf het, is in die ontleding veral gebruik gemaak van Shipley (1972), Grové (1976), HAT (Odendal et al., 1981), Cloete (1992) en Vosloo (2003) se beskrywings van die verskillende verwante vorme van parodie - meer spesifiek die burleske. 
Vervolgens word 'n enkele parodie (Müller, 2006) in meer besonderhede bespreek, as voorbeeld van die burleske, dialoog tussen kodes, postmoderne metafiksie en manifestasie van kreatiewe denke. Die outeur van die parodie is 'n wit, manlike, 23-jarige student.

\subsection{Bespreking van "O, Griet! Skryf 'n parodie"}

Die parodie "O, Griet! Skryf 'n parodie" bestaan uit twee aparte verhale ("Grietjie en Hansie" en "Die storie van die twee vuil kinders"). Dit is veral "Grietjie en Hansie" wat die studentelewe op groteske wyse uitbeeld, waar Grietjie 'n eerstejaarstudent is, en Hansie haar patetiese broer. Hulle gaan oudergewoonte en dronk ná hulle laatnaggekuier in die dorp na die McDonalds by die BPstasie om hulle hongerpyne te stil. "Die storie van die twee vuil kinders" handel oor twee kinders wat in die Bos bly, niks kan doen wat reg is nie en tog uiteindelik 'n plan maak om na die heks se huis te gaan.

\subsection{1 "Grietjie en Hansie" as voorbeeld van die burleske}

Volgens Genette (1997:22) is veral die burleske meer geneig tot die groteske. Die "Grietjie en Hansie"-parodie as deel van die parodie "O, Griet! Skryf 'n parodie" (Müller, 2006) vertoon duidelike kenmerke van spesifiek die burleske (Grové, 1976:17), met klugtige, komieklike voorstellings waar spottend-ironiese nabootsings op so 'n wyse is dat die banale en alledaagse oordrewe groots en belaglik voorkom. Voorstellings van karakters in sprokies word op 'n karikatuuragtige wyse in die parodieteks nageaap. Hierdie verhaal toon tekens van die groteske wanneer studentebedrywighede lagwekkend uitgebeeld word met sterk sardoniese en satiriese trekke byvoorbeeld Hansie se "pyn-moroniese vaardighede", Grietjie se gesmeerde make-up gesig en skelwoorde, die vertraagde bewegings ("slow motion") as uitbeelding van Hansie se lyf wat sy kop volg as hy val, Hansie wat "krul onder haar duim-en-voorvingergreep en ... kort tjankgeluidjies [kerm]" en lomp op die grond rondploeter. 'n Bekende studentewêreld word vanuit 'n perspektief betrag wat dit eensklaps vreemd laat voorkom met komiese en tog vreesaanjaende gevolge.

\subsubsection{Dialoog tussen kodes}

Hier kan melding gemaak word van die titel "O, Griet! Skryf 'n parodie" wat op dubbelsinnige wyse na twee intertekste, behalwe die gekose sprokie, verwys, naamlik die woorde "O Griet!" van die hoofkarakter in Liewe Heksie (Verna Vels, 2002) as sy per ongeluk 
haar perd optoor en Marita van der Vyver se roman Griet skryf 'n sprokie (1992).

Ter sake is ook transtekstuele verwysings in die parodieë (vgl. Genette, 1997:3 se uiteensetting van intertekstualiteit en argetekstualiteit). Voorbeelde van paratekste word gevind in "Grietjie en Hansie" waar die subtitel "n Bos parodie" is. Wat interessant is, is dat Genette (1997:23) ook verwys na 'n soortgelyke parodie, naamlik "Parody of a forest" (Bois de Vincennes), iets waarvan die outeur van die parodie nie bewus was nie (soos vasgestel in 'n opvolggesprek; vgl. Kruger, 2006a). Die feit dat die twee woorde noukeurig apart geskryf word, dui op 'n doelbewuste dubbelsinnigheid - dié bos-parodie gee vir die leser 'n aanduiding van die omgewing waarin die verhaal afspeel, naamlik die populêre studentenaam vir Stellenbosch. Om "bos te wees" of "bos te gaan" beteken in studentetaal ook om "woes of wild of onbeskaaf" te wees. Daar is ook twee spreekwoorde (Prinsloo, 2004:41) waarmee dit verband kan hou, naamlik "deur die bome die bos nie sien nie" (wat beteken dat die leser nie die geheel sien nie as gevolg van te veel kleinighede) en "iets wat agter elke bos uitgeskop kan word" (wat kan verwys na die studentebedrywighede wat volop is). Die leser se assosiasie met "bossies" of "bosbefok" kan selfs ook opgeroep word as gevolg van 'n kombinasie van die kru taalgebruik en die verwysing na die bos dus 'n plat beskrywing van 'n "versteurde geestestoestand as gevolg van 'n traumatiese gebeurtenis of oormatige spanning" (Van Wyk, 2003:63-64). Verder is dit ook 'n verwysing na die oorspronklike teks (en baie sprokies) wat in die bos afspeel.

Outografiese paratekstualiteit kom in die verhaal voor, waar die skrywer tussen hakies of in 'n parentese 'n soort verduideliking gee of kommentaar lewer, waarskynlik om die leser te begelei in die dekoderingsproses en te verduidelik wat bedoel word. In "Grietjie en Hansie" verduidelik die skrywer byvoorbeeld hóé laat dit is as hy sê "Die son kom oor twee ure op en die Bos draai al klaar", ook later as Hansie naar voel, is daar "Veels te veel rosyntjiesap".

\subsubsection{Postmoderne metafiksie}

"O, Griet! Skryf 'n parodie" het as subtitel die parateks "Twee sprokies op die maat van 'n Opdrag". Die tweede gedeelte van hierdie parodieteks verdien spesifieke aandag, omdat dit die enigste parodie (in die onderrigprogram) is wat metafiksionele elemente het. In hierdie verband merk Rose (1993:91) op: 
one of the most appropriate literary forms for the author would be the meta-fictional self-parody, in which is reflected not only his literary models, but his own more ironic and sophisticated style, and in the interruption by the host, the role of the reader as interpreter of the text.

"Die storie oor daai twee stink vuil kinders" (Müller, 2006) bevat metafiksionele narratiewe wat na die skryfproses self verwys. Dit is gelaai met onderbrekings deurdat die outeur se bedoeling op die voorgrond gestel word as deel van die narratief. Gedurig is daar ' $n$ ondermyning van die sogenaamde romantiese gelukkige einde van sprokies. Die vertelling van die sprokie is baie lomp, feite word geïgnoreer of vergeet en onbenullighede word die heeltyd herhaal. Voorbeelde hiervan is "net-net netnou, kort voor netnou" wat eintlik niks sê van die tyd nie en sprokies se bekende inleiding van "lank, lank gelede" omkeer. Die woud is vol "blommetjies en bytjies en boompies en ander wouderige dinge wat 'n mens sou verwag in ' $n$ woud sal wees" en hiermee word die romantiese milieu van gewone sprokies afgebreek. Wanneer die verteller van die karakters praat, herhaal hy dit aanhoudend: "Bosmense, of mense van die bos ... oftewel, mense. Bosmense." Op hierdie manier bied die outeur se metafiksionele onderbrekings 'n relativistiese perspektief van sowel die werklikheid as die skryfproses waar daar geen onderskeid tussen illusie en waarheid, fiksie en werklikheid, waarheid en valsheid gemaak kan word nie (vgl. Rose, 1993:98).

Aanvanklik kan die "Die storie oor daai twee stink vuil kinders" vir die leser net droogweg snaaks wees en die portuurlesers in die navorsingsprogram het nie eintlik eers enige aandag aan hierdie teks gegee nie; hulle het almal gedink daar gaan nie baie in hierdie verhaal aan nie. Mettertyd het die navorser se ontleding aangetoon dat die teks 'n voorbeeld is van wat Hutcheon (1985:88) die manipulerende outoriteit van die enkodeerder noem. Dit het die vraag laat ontstaan of hierdie teks dalk 'n tipiese onsin-humoristiese teks is soos wat Ruch (1999) bespreek as die voorkeur van manlike adolessente vir absurde en (passief-)aggressiewe humor.

In die refleksie-onderhoud wat die navorser met die onderwysstudente as deel van die navorsingsprogram gevoer het (Kruger, 2006a), het die student wat die outeur van hierdie parodie is, melding gemaak van sy aanbieding van die gedig "xenomanie" deur Clinton V. du Plessis (Vermaak, 2001:39) aan matriekleerders en hoe hy die leerders se rebelsheid teenoor ontleding van gedigte geïntegreer het met die lesinhoud. Dat hierdie gedig 'n represen- 
tasie is van Generasie $X / Y / Z$ se behoefte aan kreatiwiteit en nuwigheid, is opvallend. Die digter van hierdie gedig sê self:

Dit is die probleem met die hedendaagse jeug: hulle dra dieselfde klere, almal is ewe cool, en die grootste gemene deler is selfone en die aantal desibels op jou motorradio ... Jongmense moet meer boeke lees en minder televisie kyk. Ons word gebombardeer met goedkoop Amerikaanse snert, asof die Amerikaanse kultuur dié kultuur is. Ek dink ook gedigte moet meer verbruikersvriendelik verpak en aangebied word. Op skool byvoorbeeld het die grootste gros gedigte niks te doen gehad met die realiteite waarmee baie van ons bekend was nie (Vermaak, 2001:38).

'n Interpretasie van hierdie student se inleiding tot die parodie, sy beplanning en refleksies op die onderrigprogram aan die hand van Zuckerman (1994) se studies, maak die gevolgtrekking moontlik dat die outeur gefrustreerd en verveeld was met die proses en die opdrag. Die student se kreatiwiteit en die noodsaak om vir 'n beoordelingspunt te werk, het hom wel gestimuleer om een van die beste pogings te lewer. Die meeste van die portuurlesers het "Grietjie en Hansie" beskou as "skokkend, maar skerp" en "die beste" (Kruger, 2006a:177).

"Die storie oor daai twee stink vuil kinders" het ook 'n parateks waarin die sarkasme dadelik sigbaar is, naamlik "of so iets". Verder is daar heelwat voorbeelde van metatekste waarin die outeur met die leser kommunikeer en op 'n manier sy eie vertelling met ironie ondermyn. Op hierdie manier neem die outeur die rol van 'n gids in, wat die begrip van die leser begelei en beheer deur dit wat Hutcheon (1985:89) noem: "the best way to demystify power is to reveal it in all its arbitrariness".

Hierdie parodie het dus 'n postmoderne selfrefleksiwiteit waarmee die outeur deur middel van ironie sy eie passiewe aggressie relativeer. Dit sluit aan by die vervreemdingstegniek eie aan postmodernisme wat Belsey (1980, aangehaal in Hutcheon, 1985:91) bespreek as "a dialectical relationship between identification and distance which enlists the audience in contradiction". Die parodie skep dus afstand aan die een kant, maar betrek ook die leser in 'n deelnemende hermeneutiese aktiwiteit.

Die navorser se verklaring van 'n eie aanvanklike onbegrip en die portuurlesers se gebrek aan belangstelling (indifference) met betrekking tot hierdie parodie, is dat ironie volgens Kerbrat-Orecchioni (1980, aangehaal in Hutcheon, 1985:94) drie vaardighede van die 
leser vereis, naamlik linguistiese begrip van parodie as styl en ironie as retoriese meganisme, retoriese of generiese vaardigheid om die literêre norme van die parodie te herken, en ideologiese bewustheid om die parodie se estetiese dubbelstemmigheid te realiseer en te kontekstualiseer. Terwyl die studente naïewe lesers van die tekste was, het die navorser se eie begrip mettertyd in die navorsingsproses ontwikkel tot groter generiese leesvaardigheid.

Hierdie parodieteks maak dit duidelik dat die parodie baie vaardigheid en kritiese begrip van sowel die enkodeerder as die dekodeerder vereis. Volgens Poirier (1968, aangehaal in Hutcheon, 1985:96) is kenmerke van sowel die outeur as die leser van die parodie dat hulle "encyclopedic, learned, obsessively cultured, ... burdened with the wastes of time, with cultural shards and rubbish" behoort te wees en gevatheid moet kan verstaan om sulke tekste esteties en ideologies te interpreteer. Die parodie se outeur is beslis belese, woordvaardig en hoogs kreatief - die humorbelangstellingsvraelys wat in die navorsingsprogram gebruik is (Kruger, 2006a:375378 ), toon aan dat hy die enigste student is wat bekend is met (en hou van) ander parodieë in Engels, naamlik dié van Terry Pratchett, die Bart Simpson TV-reeks en Asterix-strokiesverhale.

\subsubsection{Manifestasie van kreatiewe denke}

Domino et al. (2002:20), Babad (1973:621,625) en Shade (1999:47) se navorsing toon aan dat dit veral met betrekking tot divergente denke is wat humor met kreatiwiteit verband hou. Flack (1997:124) maak gebruik van Guilford (1950) se konsepte van vlotheid, buigsaamheid, oorspronklikheid en uitbreiding om nuwe verhale te skep. Hierdie vier kategorieë is gebruik om vas te stel in watter mate studente in die navorsingsprogram (Kruger, 2006a) se parodietekste manifestasies van divergente denke is.

Die ontleding van die spesifieke parodie wat hier bespreek word (Müller, 2006), dui op heelwat tekens van vlotheid, omdat dit uitdrukking gee aan die vermoë om kwantitatief baie nuwe idees as response op die opdrag te genereer. Deur middel van verskeie assosiasies met die studentekultuur word 'n gedetailleerde beskrywing van die omgewing gegee, wat die outeur se besondere woordvaardigheid toon. Ook is die parodieteks 'n manifestering van uitbreiding deur die basiese idees van die oerteks interessanter en vollediger binne 'n nuwe konteks te maak: ou idees van die tradisionele Hansie en Grietjie-sprokie, wat uitgebrei en ontwikkel word in 'n omvangryke en komplekse intrige wat met konsekwensie voltooi word. Die uitbreiding behels 'n omkering van die volgorde 
van die karakters se name en 'n eietydse beskrywing van die drama wat op Woensdagaande in die studentedorp afspeel. Wat oorspronklikheid betref, toon die parodie die outeur se vermoë om slim, unieke idees in die bekende studentekultuur met nuwe organisasie van persone, plekke, objekte en dialoog te inkorporeer. Dit is veral wat buigsaamheid betref dat die student kreatiwiteit toon, naamlik om die idees in 'n verskeidenheid kategorieë, vloeiende styl en aanpassing van die oerteks in sy persepsie van die SuidAfrikaanse studentekultuurkonteks te kan plaas.

Eco (1986:275) merk op dat humor 'n spel met grense en reëls is. Hierdie siening word onderskryf deur Cook (2000) se bespreking van die skryf van parodieë as nabootsing van 'n bestaande vorm, asook Bakhtin se konsep van die karnavaleske as simboliese aggressie en gewettigde rebellie, en spel met sosiale taboes. Die taboes in 'n samelewing waarmee deur komediante en die meeste populêre kultuurmediavorme gespot word, is veral seksuele verhoudings, godsdiens en aggressie in sosiale groepe.

Hierdie soort humor is by die onderrigmateriaal ingesluit as bestaande voorbeelde van parodieë op sprokies (Dahl, Garner, De Vos se tekste). Daarmee word die studente se kreatiwiteit en divergente denke gestimuleer en hulle gerus gestel dat hierdie soort humor binne die konteks van die navorsingsprogram toegelaat word; asook dat hulle vryheid het om op hierdie manier in hulle spot met die samelewing te oortree. Dit is interessant om die portuurlesers se meestal (geskokte) response as herkenning hiervan te sien, want hulle het nie die konteks verstaan nie en het die welvoeglikheid daarvan betwyfel.

Dit is veral taboeverbrekings (kru taal en slengwoorde) wat ' $\mathrm{n}$ aanduiding gee van die outeur se spel met grense. Wat kru taal betref, word in "Grietjie en Hansie" verskillende variasies van die "f"woord gebruik (20 keer). Casper de Vries se dokument met variasies op hierdie woord is nie as onderrigmateriaal gebruik nie, maar is wel in die klasgesprekke vermeld en deur die studente self onderling versprei. Een van die portuurlesers het opgemerk dat dit tipies die taalgebruik van 'n dronk eerstejaarsmeisie is. In die parodie is dit meestal Grietjie wat hierdie woord gebruik om haar aggressie en frustrasie uit te druk. Hansie dink dit wel een maal, ook dat sy fyn motoriese vaardighede in hul "moer" is, maar hy gebruik dit nooit in sy dialoog nie. Grietjie noem ook vir Hansie 'n "klein doos" en dan dink hy dat hy "nie daarvan weet nie" (bekende woorde van die Liewe Heksie-karakter). 
Verder is daar ' $n$ herhaalde gebruik van slengwoorde in die parodie, wat algemene studentetaal is (Marais \& Coetzee, 2005), maar beslis nog nie in woordeboeke gevind word nie. Voorbeelde hiervan is Grietjie en Hansie wat by McDonald's rock-op, Grietjie se makeupgesig, die overall cleaner-tannie, die posters teen die lamppaal voor die pub, die chicken wat Grietjie bestel, McDonald's wat gesue word, Hansie wat miljoene uit 'n settlement kry en die heks wat die cash-register leeg steel.

Omdat taboeverbreking 'n soort humor is wat in sowel situasie- as woordhumor voorkom, is Van Niekerk (2001:53-59) se humormodel gebruik om die situasiehumor, wat die studente gebruik het om met hulle samelewing te spot, te ontleed. Die analise van die student se gebruik van situasiehumor toon aan dat dit veral die implisiete leser se herkenning van die situasie is wat oorheers. Meestal is dit geskep deur oordrewe uitbeelding, die hoofkarakters se penaries waaruit hulle sukkel om los te kom, krisismomente waarin die karakter se lot verander en 'n verrassingsmoment, waar die verhaal anders eindig as in die oorspronklike sprokie.

Omdat die parodie ontleen is aan 'n bekende sprokie, is daar nie baie nuwe moontlikhede om verwagting te skep nie. Tog skep die omkering van die karaktername in "Grietjie en Hansie" reeds verwagting by die implisiete leser dat hier iets anders is as die bekende sprokie. Die parodieteks veroorsaak verder 'n gevoel van meerderwaardigheid deur middel van indirekte bevestiging by die leser, juis omdat die hoofkarakter deur karikaturisering en die situasie deur oordrywing gegenereer is.

Behalwe die kru taal en slengtaal wat reeds as taboeverbrekings bespreek is, bevat die student se parodieteks ook linguistiese elemente wat gebruik is om met die samelewing te spot. Om die frekwensie van die student se spel met klank, leestekens en woorde in hul parodietekste te vind, is die teks ontleed aan die hand van Van Niekerk (2001:53-59) se model, maar dit is ook aangevul uit Calitz (1979:25-49). Wat duidelik uit die ontleding van die parodieteks na vore kom (Kruger, 2006a:185-6), is dat duidelike patrone gevind kan word in die student se gebruik van woordhumor, waarmee hy met die implisiete leser in interaksie tree (Iser, 1972, aangehaal in Bosman, 1987:13) om die situasies waarmee hy spot, te herken. Die volgende patrone word onderskei: sinestesie word gebruik om woordprente te skep, soms deur ouditiewe klankmanipulasie of oksimoron en andersins deur visuele oordrywing en effektiewe leestekengebruik. Die oordrywing vind veral plaas deur hiperbole, vergelykings, repetisie, of opstapeling van besonderhede. 
Soms word hierdie oordrywing veroorsaak deur die kontras wat eufemisme en litotes (dus verkleining) geskep het.

Die leser se logiese en kritiese denke word betrek deur die outeur se gebruik van ironie, sarkasme, dubbelsinnigheid en woordspelings. Daar word soms ook op die leser se herkenning van situasies aanspraak gemaak deur die gebruik van clichés en streekstaal. In baie gevalle vind die leser se deelname aan die leesaksie deur middel van slengtaal (alledaagse omgangstaal van studente) plaas. Die leser kan die situasie wat beskryf word deur middel van kru taal herken. Die outeur maak geen gebruik van intensiewe vorme om te oordryf nie, wel enkele vergelykings en hiperbole.

Die outeur skep dikwels deur middel van suggestie oop plekke (Iser, 1976, aangehaal in Bosman, 1987:13) wat aanspraak maak op die leser se verbeelding en hom/haar uitnooi om deel te neem aan die spot met die samelewing. Idiomatiese uitdrukkings word gebruik waardeur die leser se verbeelding geprikkel word, omdat dit meestal figuurlike taalgebruik is wat 'n letterlike betekenis veronderstel. Die outeur voer dialoog met die leser se verwagtingshorison (Jauss, 1979, aangehaal in Bosman 1987) deur van spottery gebruik te maak.

Wanneer daar gelet word op die totale hoeveelheid situasie- en woordhumorelemente waarvan studente in die navorsingsprogram gebruik gemaak het om te spot, is dit duidelik dat hierdie parodie hipoteties die snaaksste moes wees in vergelyking met die res van die groep studente wat aan die navorsingsprogram deelgeneem het. In die portuurleesprogram het dit ook duidelik so geblyk te wees, hoewel sommige lesers die kru taal skokkend (selfs aanstootlik) gevind het.

\section{Samevatting}

Die "O Griet! skryf 'n parodie"-teks toon 'n intertekstuele digtheid met nabootsing en verwringing van die oorspronklike teks vir satiriese doeleindes. Die parodieskrywer gebruik 'n verskeidenheid stylmiddele, van dubbelsinnigheid en klankspel tot oordrywing, inkongruensie en verwysings wat 'n dubbele stel seine genereer: een wat die oorspronklike teks oproep en die ander wat daarmee speel. Laasgenoemde gebeur omdat die parodieskrywer met die oorspronklike teks se betekenis speel, deurdat hy daardeur aangetrek is, en tog ook daarvan wou ontsnap deur die waardes te ondermyn wat in die sprokies geënkodeer is. Die gevolg van hierdie spel was literêre kreatiwiteit. 
Terwyl daar gespot word met die swakhede en uitspattighede merkbaar in die samelewing waarin studente leef, het die parodie as literêre stylfiguur vir die outeur die moontlikheid gebied om op kreatiewe manier sy stem daaroor te verhef, waar hy dalk andersins nie die moed sou hê om dit so direk te doen nie.

Die parodiese teks skep verwagtings by die leser deurdat dit (deur middel van styl of implikasie) ooreenkomste toon met die oorspronklike sprokieteks, maar doelbewus hierdie verwagtings "frustreer", deur definitief verskillend daarvan te wees. Nie al die portuurlesers in die navorsingsprogram was ewe beïndruk hiermee nie, maar dit het meestal bygedra tot baie kreatiewe energie en humor in portuurgesprekke. Verder is die parodie slegs effektief as die leser op die dubbele stel seine daarin teenwoordig reageer; nie alle lesers toon waardering hiervoor nie.

Die parodieteks wat deur hierdie student in die navorsingsprogram geskep is, is nie bedoel om op skool gebruik te word wanneer die student as onderwyser in die onderwyspraktyk werksaam is nie die gebruik van kru taal sou dit waarskynlik nie geskikte onderrigmateriaal maak nie. Gedurende die navorsingsprogram het die student wel die vryheid gehad om die teks te skryf vir Kurrikulumstudie-doeleindes en dit was 'n waardevolle oefening in die ontwikkeling en onderrig van kreatiewe skryfvaardighede. Die vraag ontstaan wel of ironie en satire aangewese vorme is om kreatiewe skryf op hoërskoolvlak te stimuleer. Die navorser meen tog dat adolessente oor die verwysingsraamwerk beskik om sprokies as oertekste te gebruik om parodieë te kan skryf. Die feit dat Bartho Smit se Die keiser (1977) in 2005 voorgeskryf is vir graad 12leerders in die Wes-Kaap (Wes-Kaapse Onderwysdepartement, 2005) veronderstel ook dat die parodie as stylfiguur binne hulle leesagtergrond geïntegreer kan word (Departement van Onderwys, 2003:39). In elk geval kan die insluiting van hierdie soort skryftake bydra tot ' $n$ betekenisvolle uitbreiding van hulle kulturele geletterdheid.

Die gebruik van humormateriaal kan help om 'n positiewe leeromgewing te skep. Voorbeelde hiervan wat geskik is vir gebruik in die taalonderrigsituasie kan gevind word in die massamedia soos televisie en tydskrifte. Pikturale humor soos in spotprente, humoristiese illustrasies en strokies spreek veral tot kinders wat geneig is om die modes, houdings, gebare en komiese uitdrukkings van hulle heldefigure na te boots (Verster, 2003). Die relevansie van hierdie voorbeelde is dat sowel aspirant-onderwysers as sekondêre leerders wat deelgeneem het aan die navorsingsprogram (Kruger, 
2006a) wat as agtergrond vir hierdie artikel dien, skeppers en gebruikers van genoemde media is. Ook ten opsigte van klaskamerdissipline kan die gebruik van humormateriaal 'n alternatiewe onderrigstrategie bied. Dit kan 'n bydrae lewer tot 'n belewing en kreatiewe uitdrukking van emosies en rebellie in die taalklaskamer en dit kan leerders se affektiewe en kritiese ontwikkeling bevorder.

\section{Geraadpleegde bronne}

ABDALLAH, A. 1996. Foster creativity in student teachers. Community review, 14:p. Available: EbscoHost, Academic Search Premier. Date of access: 4 Dec. 2003.

ALDERMAN, D.H. \& POPKE, E.J. 2002. Humor and film in the geography classroom: learning from Michael Moore's TV Nation. The journal of geography, 101(6):228-239.

AOKI, N. 1999. Affect and the role of teachers in the development of learner autonomy. (In Arnold, J., ed. Affect in language learning. Cambridge: Cambridge University Press. p. 142-154.)

APTE, M.L. 1985. Humor and laughter: an anthropological approach. Ithaca: Cornell University Press.

BABAD, E.Y. 1973. A multi-method approach to assessment of humor: a critical look at humor tests. Journal of personality, 42(4):618-631.

BABBIE, E. \& MOUTON, J. 2001. The practice of social research. New York: Oxford University Press.

BAND, A.J. 1990. Swallowing Jonah: the eclipse of parody. Prooftexts, 10:177195.

BELZ, J.A. 2002. Second language play as a representation of the multicompetent self in foreign language study. Journal of language, identity and education, 1(1):13-39.

BERK, R.A. 1998. Professors are from Mars, students are from Snickers: how to write and deliver humor in the classroom and in professional presentations. Wisconsin: Mendota.

BOSCH, B. 1995. Taalgesindhede en die onderrig van Afrikaans. Per linguam, 11(1):14-24.

BOSMAN, M. 1987. Die hoërskoolleerling as leser. Pretoria: Raad vir Geesteswetenskaplike Navorsing.

BRONER, M.A. \& TARONE, E.E. 2001. Is it fun? Language play in a fifth-grade Spanish immersion classroom. The modern language journal, 85(3):493525.

BRYANT, J., COMISKY, P. \& ZILLMANN, D. 1979. Teacher's humour in the college classroom. Communication education, 28(2):110-118.

CALITZ, F.C. 1979. Spot, skel en verwante verskynsels in Afrikaans. Stellenbosch: Universiteit van Stellenbosch. (Ongepubliseerde D.Lit.-proefskrif.)

CHIASSON, P.E. 2002. Using humour in the second language classroom. The internet TESL journal, 8(3). http://iteslj.org Date of access: 4 Nov. 2003.

CLOETE, T.T., red. 1992. Literêre terme en teorieë. Pretoria: HAUM.

COOK, G. 2000. Language play, language learning. Oxford: Oxford University Press. 
COUTURIER, R.L., MANSFIELD, R.S. \& GALLAGHER, J.M. 1981. Relationships between, humor, formal operational ability, and creativity in eighth graders. Journal of genetic psychology, 139:221-226.

CRAWFORD, M. \& GRESSLEY, D. 1991. Creativity, caring and context. Psychology of women quarterly, 15:217-231.

CURNUTT, K. 1996. Parody and pedagogy: teaching style, voice, and authorial intent in the works of Gertrude Stein. College literature, 23(2). Available: EbscoHost, Academic Search Premier. Date of access: 12 Apr. 2005.

DAHL, R. \& BLAKE, Q. 1982. Revolting rhymes. London: Penguin Books.

DE BONO, E. 1990. I am right, you are wrong: from this to the New Renaissance: from rock logic to water logic. London: Viking.

DE VOS, P. \& GROBLER, P. 1999. Kat se blad: stuitige strokies. Kaapstad: Human \& Rousseau.

DEPARTEMENT VAN ONDERWYS. 2003. Nasionale Kurrikulumverklaring Grade 10-12 (skole). Kaapstad: Departement van Onderwys.

DEWITTE, S. \& VERGUTS, T. 2001. Being funny: a selectionist account of humor production. Humor, 14(1):37-53.

DOMINO, G., SHORT, J., EVANS, A. \& ROMANO, P. 2002. Creativity and ego defense mechanisms: some exploratory empirical evidence. Creativity research journal, 14(1):17-25.

DREYER, J.A.E. 2005. 'n Opleidingsprogram in alternatiewe interaksiemetodes vir onderwysers. Pretoria: Universiteit van Suid-Afrika. (Ongepubliseerde D.Ed.-proefskrif.)

ECO, U. 1986. Travels in hyperreality. London: Pan Books.

ENDLICH, E. 1993. Teaching the psychology of humor. Teaching psychology, 20(3):181-183.

FEINGOLD, A. \& MAZZELLA, R. 1993. Preliminary validation of a multidimensional model of wittiness. Journal of personality, 61(3):439-456.

FLACK, J. 1997. From the land of enchantment: creative teaching with fairy tales. Colorado: Teacher Ideas Press.

FREUD, S. 1916. Jokes and their relation to the unconscious. New York: Penguin.

FRY, W.F. \& ALLEN, M. 1996. Humor as creative experience: the development of a Hollywood humorist. (In Chapman, A.J. \& Foot, H.C., eds. Humor and laughter: theory, research and applications. London: Transaction Publishers. p. 245-258.)

GARNER, J.F. 1994. Politically correct bedtime stories. London: Souvenir.

GENETTE, G. 1997. Palimpsests: literature in the second degree. Lincoln: University of Nebraska Press.

GROVÉ, A.P., red. 1976. Letterkundige Sakwoordeboek vir Afrikaans. Kaapstad: Nasou.

GUILFORD, J.P. 1950. Fields of psychology: basic and applied. Princeton: Van Nostrand.

HERANGI, B. 2002. So, like, what's these Xers, man? (In Tiplady, R., ed. Postmission: world mission by a postmodern generation. Cumbria: Paternoster. p. 2-13.)

HONIG, A.S. 2001. How to promote creative thinking. Early childhood today, 15(5). Available: EbscoHost, Academic Search Premier. Date of access: 3 Nov. 2003.

HUTCHEON, L. 1985. A theory of parody. London: Methuen. 
KENWAY, J. \& BULLEN, E. 2001. Consuming children: education - entertainment - advertising. Buckingham: Open University Press.

KHER, N., MOLSTAD, S. \& DONAHUE, R. 1999. Using humor in the college classroom to enhance teaching effectiveness in "dread courses". College student journal, 33(3). Available: EbscoHost, Academic Search Premier. Date of access: 8 Feb. 2002.

KIRSH, G.A. \& KUIPER, N.A. 2003. Positive and negative aspects of sense of humor: associations with the constructs of individualism and relatedness. Humor, 16(1):33-62.

KOESTLER, A. 1969. The act of creation. London: Pan Books.

KRUGER, E. 2006a. Die gebruik van humormateriaal in die onderrig van Afrikaans. Stellenbosch: Universiteit van Stellenbosch. (Ongepubliseerde Ph.D.-proefskrif.)

KRUGER, E. 2006b. Onderwysstudente se parodieë as hibridiese tekste: 'n navorsingsverslag. Literator, 27(2):83-108.

KUHRIK, M., KUHRIK, N. \& BERRY, P.A. 1997. Facilitating learning with humor. Journal of nursing education, 36(7):332-334.

LANDVOGT, J. 2001. Affecting eternity: teaching for talent development. Roeper review, 23(4):190-197. Available: EbscoHost, Academic Search Premier. Date of access: 3 Nov. 2003.

LYTTLE, J. 2001. The effectiveness of humor in persuasion: the case of business ethics training. Journal of general psychology, 128(2). Available: EbscoHost, Academic Search Premier. Date of access: 8 Feb. 2002.

MALAN, M.G. 1996. Kreatiwiteitspotensiaal van 'n groep staatsamptenare. Stellenbosch: Universiteit van Stellenbosch. (Ongepubliseerde M.A.verhandeling.)

MARAIS, S. \& COETZEE, A. 2005. Tienerafrikaans. Tydskrif vir taalonderrig, 39(2):244-259.

MCGHEE, P.E. 1979. Humor: its origin and development. San Francisco: Freeman.

MEDGYES, P. 2002. Laughing matters: humour in die language classroom. Cambridge: Cambridge University Press.

MINCHEW, S.S. 2001. Teaching English with humor and fun. American secondary education, 30(1):58-70.

MÜLLER, A. 2006. O Griet, skryf 'n parodie. Literator, 27(2):215-219.

NEHRING, N. 2003. Jigsaw youth versus generation $X$ and postmodernism. (In Ulrich, J.M. \& Harris, A.L., eds. GenXegesis: essays on alternative youth (sub)culture. Wisconsin: Wisconsin University Press. p. 59-78.)

NILSEN, A.P. \& NILSEN, D.L.F. 1999. The straw man meets his match: six arguments for studying humor in English classes. English journal, 88(4):34-42.

ODENDAL, F.F., SCHOONEES, P.C., SWANEPOEL, C.J., DU TOIT, S.J. \& BOOYSEN, C.M., reds. 1981. Verklarende Handwoordeboek van die Afrikaanse Taal. Johannesburg: Perskor.

PETERS, M. 2003. The use of the useless: all I really need to know I learned as a teaching artist. Teaching artist joural, 1(4):213-219.

POLLAK, J.P. \& FREDA, P.D. 1997. Humor, learning, and socialisation in the middle level classrooms. Clearing house, 70(4):176-178.

PRETORIUS, R. 1992. Parodie. (In Cloete, T.T., red. Literêre terme en teorieë. Pretoria: HAUM. p. 370-372.) 
PRINSLOO, A.F. 2004. Spreekwoorde en waar hulle vandaan kom. Kaapstad: Pharos.

ROBERTSON, G. 1980. Kreatiwiteit: ongepubliseerde studiegids vir afstandsonderrig. Pietermaritzburg: Natalse Onderwyskollege.

ROSE, M.A. 1993. Parody: ancient, modern and post-modern. Cambridge: Cambridge University Press.

RUCH, W. 1999. The perception of humor. http://www.uni-duesseldorf.de/www/ MathsNat/Ruch/Texte/Naplesl.doc Date of access: 6 Nov. 2003.

SHADE, R.A. 1999. Humor: a course of study for gifted learners. Gifted child today, 22(1):46-49.

SHIPLEY, J.T., ed. 1972. Dictionary of world literature. New Jersey: Littlefield.

SIMONTON, D.K. 1999. Creativity as blind variation and selective retention: is the creative process Darwinian? Psychological inquiry, 10(4). Available: EbscoHost, Academic Search Premier. Date of access: 3 Nov. 2003.

SMIT, B. 1977. Die keiser. Johannesburg: Perskor.

TOROK, S.E., MCMORRIS, R. \& LIN, W.C. 2004. Is humor an appreciated teaching tool? Perceptions of professors' teaching style and use of humor. College teaching, 52(1):14-20.

ULLOTH, J.K. 2003. Guidelines for developing and implementing humor in nursing classrooms. Journal of nursing education, 42(1):35-37.

VAN DER VYVER, M. 1992. Griet skryf 'n sprokie. Kaapstad: Tafelberg.

VAN NIEKERK, J.E. 2001. Humor in kinderverhale: 'n vergelyking tussen geselekteerde Afrikaanse en Nederlandse tekste. Potchefstroom: PU vir CHO. (Ongepubliseerde M.A.-verhandeling.)

VAN WYK, G.J., red. 2003. Etimologiewoordeboek van Afrikaans. Stellenbosch: Buro van die Woordeboek van die Afrikaanse Taal.

VELS, V. 2002. Die Liewe Heksie-omnibus. Kaapstad: Human \& Rousseau.

VERMAAK, A. 2001. Versreise. Kaapstad: Tafelberg.

VERSTER, F. 2003. 'n Kultuurhistoriese perspektief op die pikturale humor van T.O. Honiball. Stellenbosch: Universiteit van Stellenbosch. (Ph.D.proefskrif.)

VOSLOO, J. 2003. Die manifestering van humor in geselekteerde Afrikaanse kortverhaaltekste. Stellenbosch: Universiteit van Stellenbosch. (D.Lit.proefskrif.)

WEBER, A. 2000. Playful writing for critical thinking: four approaches to writing. Journal of adolescent \& adult literacy, 43(6):562-568.

WEISS, R.P. 2001. How to foster creativity at work. Training \& development, 55(2). Available: EbscoHost, Academic Search Premier. Date of access: 3 Nov. 2003.

WES-KAAPSE ONDERWYSDEPARTEMENT. 2005. Finale lys van voorgeskrewe werke vir literatuurstudie: grade 7, 8, 9, 10, 11 en 12. http://curriculum.wcape.school.za/ Datum van gebruik: 15 Feb. 2005.

WHITE, G.W. 2001. Teachers' report of how they used humor with students' perceived use of such humor. Education, 122(2):337-347.

WYCOFF, E.B. \& PRYOR, B. 2003. Cognitive processing, creativity, apprehension and the humorous personality. North American journal of psychology, 5:31-44.

ZUCKERMAN, M. 1994. Behavioral expressions and biosocial bases of sensation seeking. Cambridge: Cambridge University Press. 


\section{Kernbegrippe:}

adolessensie

humor

kreatiewe skryf

kreatiwiteit

parodie

taalonderrig

Key concepts:

adolescence

creative writing

creativity

humour

language teaching

parody 
